\title{
Productivity of arctic amphipods relative to gray whale energy requirements
}

\author{
Raymond C. Highsmith, Kenneth O. Coyle \\ Institute of Marine Science, School of Fisheries and Ocean Sciences, University of Alaska Fairbanks, \\ Fairbanks, Alaska 99775-1080, USA
}

\begin{abstract}
Amphipod crustaceans dominate the benthic community in vast areas of the northern Bering Sea; they are the major prey of the California gray whale Eschrichtius robustus. The protected whale population is growing steadily and may be approaching the carrying capacity of the amphipod community, one of the most productive benthic communities in the world. The abundance and biomass of the amphipod community decreased during the 3 yr period 1986 to 1988 , resulting in a $30 \%$ decline in production. High-latitude amphipod populations are characterized by low fecundity and long generation times. Large, long-lived individuals are responsible for the majority of amphipod secondary production. A substantial reduction in the density of large individuals in the population will result in a significant, long-term decrease in production
\end{abstract}

\section{INTRODUCTION}

The northern Bering Sea benthic amphipod community, extending over an area of about $40000 \mathrm{~km}^{2}$, is an important food source for the migratory California gray whale Eschrichtius robustus (Blokhin \& Vladimirov 1981, Nerini 1984). Most of the amphipods belong to the gammaridean family Ampeliscidae, which includes a number of circumboreal, tube-dwelling species occurring on sandy substrates in shallow coastal seas (Gurjanova 1951, Dickinson 1982, 1983, Coyle \& Highsmith 1989). Several ampeliscid taxa - including Ampelisca macrocephala, A. birulai, and a Byblis species group - occur in dense populations in the Chirikov Basin, a major Bering Sea whale feeding area (Fig. 1). This species complex forms the ampeliscid community, which dominates the benthic fauna in the central Chirikov Basin (Stoker 1981, Grebmeier et al. 1989). The community is characterized by low species diversity, high organic input, high biomass (Grebmeier et al. 1988, Highsmith \& Coyle 1990), and the highest

In Memoriam. This paper is dedicated to Shelli Dawn Clay, an outstanding student at the University of Alaska Fairbanks who participated in this study during her junior and senior years. Her zest for life was a marvel and inspiration to all of us secondary production rates reported for any extensive benthic community (Highsmith \& Coyle 1990).

Gray whales annually undertake one of the longest migrations known for any mammal, from the calving lagoons of Baja California to the feeding grounds of the northern Bering, Chukchi, and Beaufort Seas (Rice \& Wolman 1971). The 8000 to $9000 \mathrm{~km}$ northward migration, spanning some $50^{\circ}$ of latitude, starts in late winter or early spring. The whales begin arriving at the Chirikov Basin in May and are present in large numbers by June (Rice \& Wolman 1971, Braham 1984). The whales typically remain on the feeding grounds until mid to late October, when the approximate 2 mo return migration begins (Braham 1984).

Other whale species occasionally feed on the sea bottom (Hazard \& Lowry 1984, Lowry \& Frost 1984), but gray whales are unique in feeding extensively on benthic infauna, primarily ampeliscid amphipods (Rice $\&$ Wolman 1971). The ampeliscids construct and live in mucous tubes that penetrate several $\mathrm{cm}$ into the sandy bottom of the 40 to $50 \mathrm{~m}$ deep study area of the Bering Shelf. Gray whales prey on the amphipods by placing one side of their mouth on the bottom and sucking out large pits (Ray \& Schevill 1974, Nerini \& Oliver 1983, Nerini 1984, Swartz \& Jones 1987). The amphipods in the sediment drawn from the pit are filtered out on the 
whale's baleen as the sediment is expelled from the other side of the whale's mouth.

Eschrichtius robustus became a protected species in the 1940s (Brownell 1977, Jones et al. 1984). The gray whale population has steadily increased since 1967 at an estimated rate of $3.2 \%$ per year (Reilly et al. 1983, Buckland in press). The latest National Marine Fisheries Series census indicated the whale population had reached 21100 individuals by 1987 (Breiwick et al. 1988), somewhat above hypothesized pre-exploitation levels of 15000 to 20000 (Berzin 1984, Henderson 1984). These estimates suggest that 500 to 600 new individuals per year are currently being added to the population. The relationship of the expanding whale population to amphipod community dynamics is unknown, but of considerable interest because of several potential ecological consequences, such as depletion of the amphipod community and long-term loss of amphipod habitat to other space-occupying species, addition of new prey species to the whales' diet and/or extension of foraging activities into new regions or habitats, or restriction of whale population growth.

This paper presents data collected over a 3 yr period on ampeliscid population densities, biomass and pro- duction in the Chirikov Basin. The production data are compared with calculations of gray whale energy requirements to evaluate the potential impact of gray whale feeding on the ampeliscid community.

\section{METHODS}

The study area (Fig. 1) is in the central Chirikov Basin between 64 and $65^{\circ} \mathrm{N}$ latitude and 168 and $170^{\circ} \mathrm{W}$ longitude. The region is typically ice covered

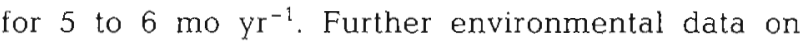
the Chirikov Basin are available in the literature (Coachman et al. 1975, Grebmeier et al. 1988, 1989, Highsmith \& Coyle 1990)

Sampling was conducted from 1986 through 1988. Four cruises per year were made to the study site: typically, the first was in late May or early June following break up, the second in July, the third in August and the fourth was made between mid-September and early November. The most accurate production estimates are obtained when sampling is concentrated on the period of maximun production (Morin et al. 1987) Sampling during periods of lower production is less

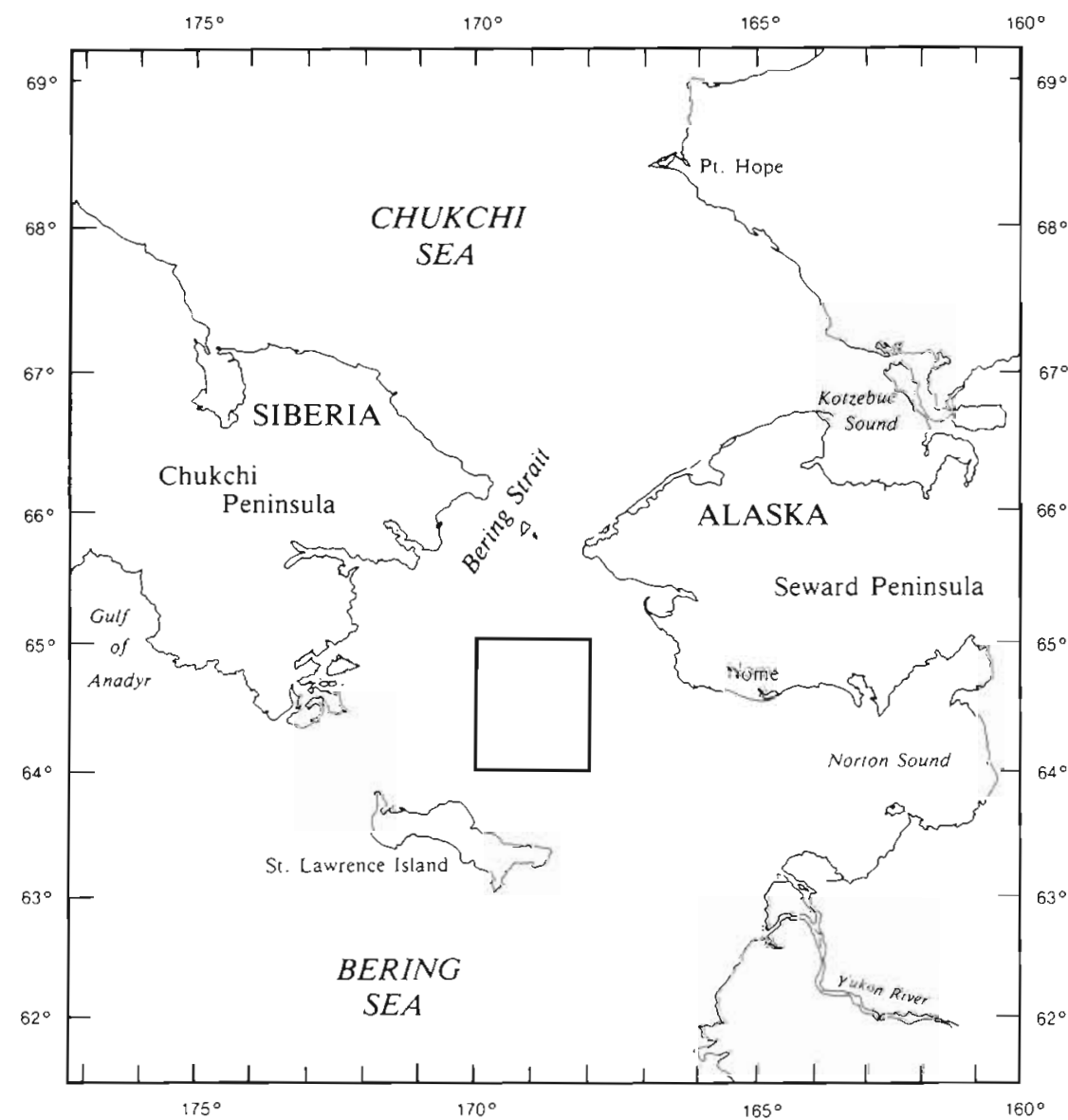

Fig. 1 Location of the Chirikov Basin study area (rectangle) in the northern Bering Sea 
critical. The lack of sample material from the winter period therefore probably does not seriously compromise our results.

Prior to the first year's field work, coordinates for 20 stations within the study area were selected using a random numbers table. The 20 stations were visited during each cruise, weather and ice permitting. Thirteen of the stations within the amphipod bed were sampled during all cruises

The amphipods were collected using a $0.1 \mathrm{~m}^{2}$ van Veen grab. The grab material was sieved through a $1 \mathrm{~mm}$ screen. All animals retained on the screen were preserved in $10 \%$ buffered formalin for later analyses. Five replicate grab samples were taken at each station. Supplemental samples were collected at 3 stations in the amphipod bed. The fresh amphipods in these samples were sorted to species, measured to the nearest $\mathrm{mm}$ (tip of head to tip of telson), dried at $60^{\circ} \mathrm{C}$ for $24 \mathrm{~h}$, and frozen for return to the laboratory. In the laboratory, after thawing and redrying at $60^{\circ} \mathrm{C}$ for $12 \mathrm{~h}$, dry weight was determined with a Cahn electrobalance and caloric content was measured with a Parr model 1241 adiabatic bomb calorimeter with semimicro attachment.

The preserved grab samples were sorted to species, and length measurements were made on each individual to the nearest mm using a dissecting microscope. The data were loaded into an INGRES data base system for analyses. Dry weight biomass was computed from regression curves generated from lengthdry weight measurements on the fresh material. Production was calculated using the cohort summation technique (Wildish \& Peer 1981). Non-parametric methods (Kruskal-Wallis tests) were used to test for differences in density, biomass and production data between years.

\section{RESULTS}

\section{Amphipod production}

The dominant ampeliscid species in both abundance and biomass over the 3 yr study was Ampelisca macrocephala (Table 1). The density of $A$. macrocephala decreased $12 \%$ from 1986 to 1987 ; biomass decreased $26 \%$. These data suggest that large individuals accounted for most of the density decrease. By 1988, the density increased to only $3 \%$ below the 1986 level, but biomass remained the same as in 1987, again indicating a size-frequency shift toward smaller individuals. Overall, the change in density was not significant but there was a significant decrease in biomass. A. birulai decreased significantly in both density and biomass during the study period (Table 1). The Byblis spp.
Table 1. Ampeliscid amphipod mean densities and biomass (dry weight) in the northern Bering Sea, 1986 to 1988. p-values: significance levels for the Kruskal-Wallis test. $N=$ 39 for 1986; $N=26$ for 1987 and 1988

\begin{tabular}{|ccc|}
\hline Year & $\begin{array}{c}\text { Density } \\
\left(\mathrm{no.}^{-2}\right)\end{array}$ & $\begin{array}{c}\text { Biomass } \\
\left(\mathrm{g} \mathrm{m}^{-2}\right)\end{array}$ \\
\hline Ampelisca macrocephala & & \\
1986 & 2520 & 42.2 \\
1987 & 2228 & 31.4 \\
1988 & 2441 & 31.9 \\
$\mathrm{p}$ & 0.2 & 0.006 \\
& & \\
Ampelisca birulai & & 3.0 \\
1986 & 928 & 2.9 \\
1987 & 743 & 2.2 \\
1988 & 700 & 0.02 \\
$\mathrm{p}$ & 0.01 & \\
& & 8.3 \\
Byblis spp. & & 5.8 \\
1986 & 1248 & 8.2 \\
1987 & 842 & 0.01 \\
$\mathrm{p}$ & 889 & \\
\hline
\end{tabular}

group also decreased significantly in both categories, with lowest values in 1987 . Density and biomass each decreased ca $30 \%$ from 1986 to 1987 . The rebound in Byblis biomass in 1988 is not accounted for by the corresponding $5 \%$ increase in density. Thus, the 1988 population was composed of individuals ca $30 \%$ larger on average than those in 1987 . For the 3 amphipod types combined, there was a $14 \%$ decrease in density and a $21 \%$ decrease in biomass from 1986 to 1988 .

Most of the decrease in density and biomass indicated above occurred between the 1986 and 1987 sampling seasons. Comparison of Ampelisca macrocephala data for the last cruise (late September) of 1986 with the first cruise (mid-June) of 1987 (Fig. 2) reveals a significant (Kruskal-Wallis test, $p<0.02$ ) decrease in biomass of individuals between 18 and $27 \mathrm{~mm}$ length. A similar, but not significant (KruskalWallis test, $p>0.3$ ), decrease in biomass for intermediate to larger individuals occurred the following winter (Fig. 3). In both cases, there was a tendency for biomass peaks to shift to ca $2 \mathrm{~mm}$ longer individuals, presumably reflecting growth between the fall and spring sampling dates. For both years, the biomass peaks at $6 \mathrm{~mm}$ length represent spring recruits, which are numerous (Fig. 4) but because of their small size do not constitute a commensurate proportion of the population biomass (Highsmith \& Coyle 1991).

The dry weight of the amphipods consistently increased during each summer (Fig. 5), with individuals of a given length weighing 12 to $14 \%$ more in November than in June. Seasonal patterns of amphi- 


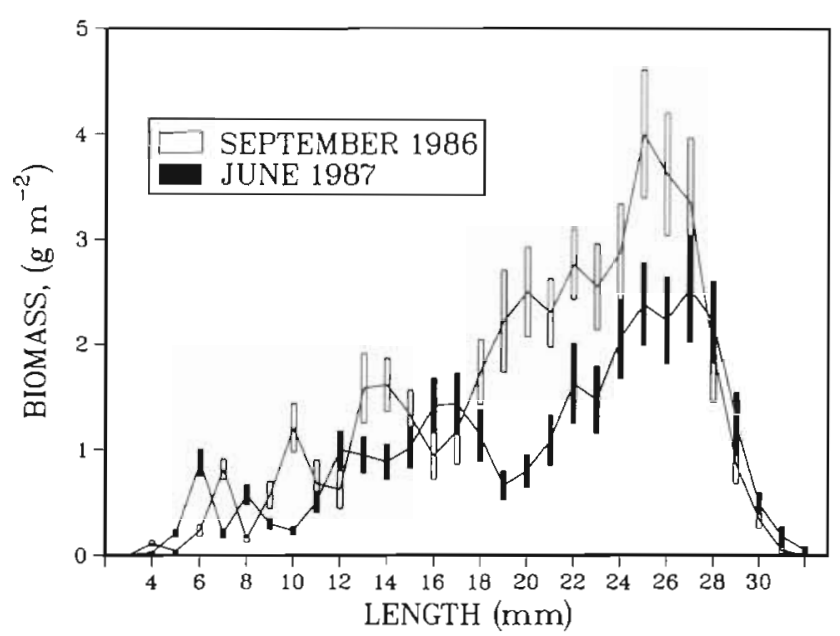

Fig. 2. Ampelisca macrocephala and Ampelisca erythrorhabdota. Changes in the length-dry weight relationship in the Chirikoy Basin during winter 1986-1987. Error bars: 1 SE from the mean. A. erythrorhabdota is included because small individuals of the 2 species are indistinguishable (Coyle \& Highsmith 1989). The latter species may account for ca $10 \%$ of the individuals (Highsmith \& Coyle 1991)

pod energy content per unit weight during 1988 (Fig. 6) were similar to 1986 (Highsmith \& Coyle 1990), with 1988 values being slightly lower. The caloric contents of Ampelisca macrocephala, A. birulai and Byblis spp. were each significantly lower in June than in July through October $(p=0.001,0.035$ and 0.001 , respectively: Kruskal-Wallis test). Apparently, the weight gains by these species during summer are due in part to the accumulation of energy storage compounds, probably lipids, used for metabolic processes during

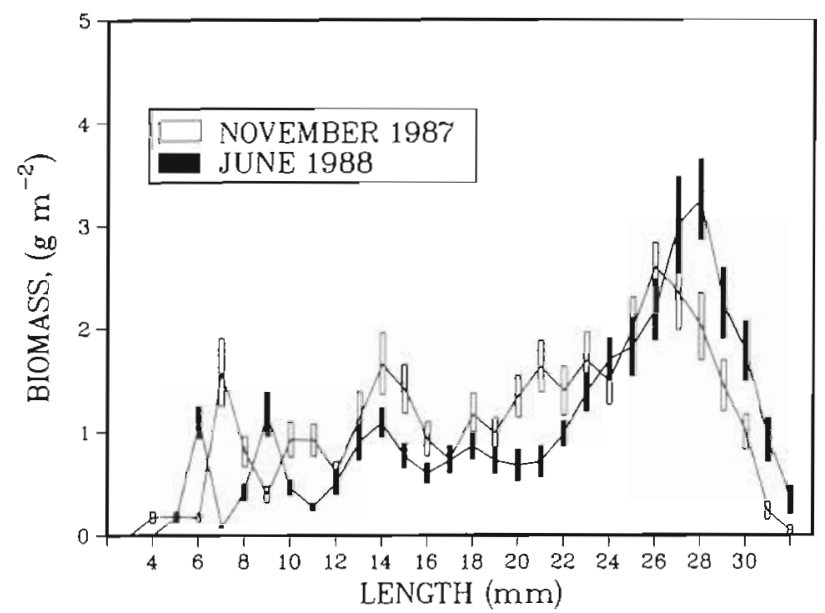

Fig. 3. Ampelisca macrocephala and Ampelisca erythrorhabdota. Changes in the length-dry weight $\left(\mathrm{g} \mathrm{m}^{-2}\right)$ relationship in the Chirikov Basin during winter 1987-1988. Error bars: $1 \mathrm{SE}$ from the mean

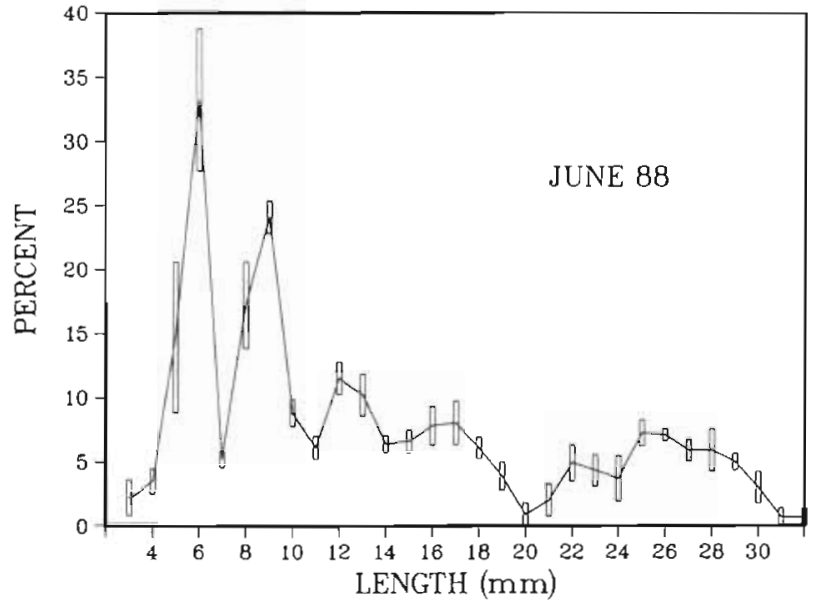

Fig. 4. Ampelisca macrocephala. Arcsine transformed length frequency distributions at Station 4 in the Chirikov Basin. Error bars: $1 \mathrm{SE}$ from the mean

the winter. A portion of the winter energy loss by the amphipods may result from egg production during winter.

The contribution of Ampelisca birulai to annual ampeliscid production was estimated based on the conservative assumption that its growth rate was similar to that of A. macrocephala. Reproduction in $A$. birulai is not sufficiently synchronous to produce distinct $c o-$ horts. A bimodal size-frequency distribution occurred at every sampling date (Highsmith \& Coyle 1991). Eggs in the brood pouches of female A. birulai collected at the same time were in varying stages of development, from bright purple new eggs, to eyed embryos nearly ready to hatch. Members of this species hatch out of the egg membrane at a length of

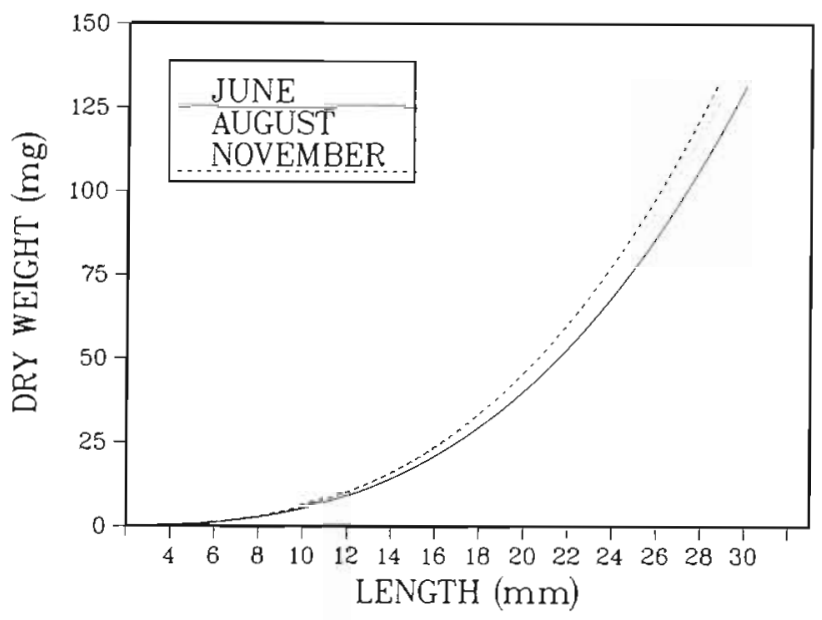

Fig. 5. Ampelisca macrocephala and Ampelisca erythrorhabdota. Length-dry weight ( $\mathrm{mg}$ ind ${ }^{-1}$ ) relationship in the Chirikov Basin during 1987 


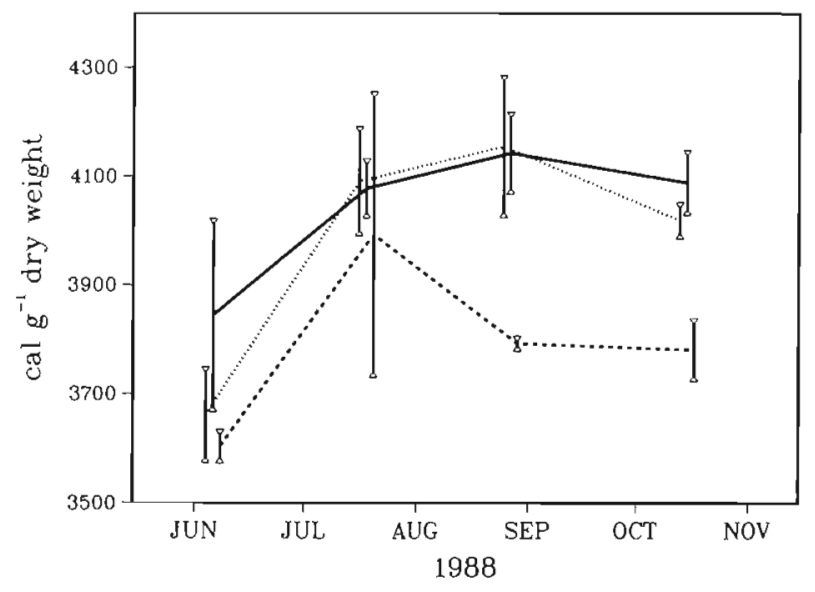

Fig. 6. Ampelisca macrocephala (-), Ampelisca birulai $(-\cdots . .-)$ and Byblis spp. (……….). Seasonal changes in the energy content in the Chirikov basin. Error bars: $1 \mathrm{SE}$ deviation from the mean

$3 \mathrm{~mm}$, reach a maximum length of $12 \mathrm{~mm}$, and appear to have a biannual life cycle (Highsmith \& Coyle 1991).

Ampelisca macrocephala was responsible for 77,72 and $75 \%$ of the total ampeliscid production for 1986 through 1988, respectively (Table 2 ). The decline in A. macrocephala production between 1986 and 1988 resulted from reduced densities of the larger-sized individuals, as mentioned above. For the ampeliscids overall, production declined 30\% from 1986 to 1988.

Production rates, converted to energy equivalents, are presented in Fig. 7 . The 6 mo production estimates are based on the data collected from late May and early June through October and early November. Since we were unable to sample during winter and

\section{AMPELISCID COMMUNITY PRODUCTION}

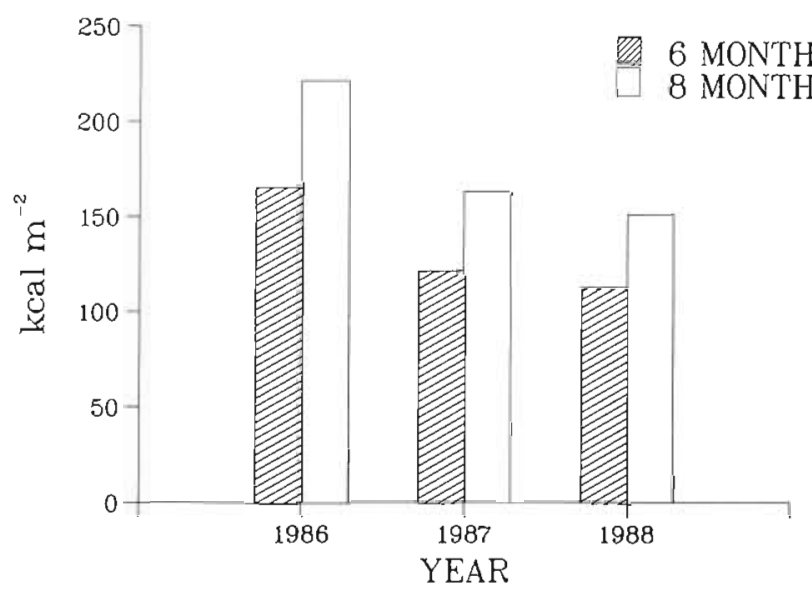

Fig. 7. Energy production of the ampeliscid community in the Chirikov basin, based on 6 and 8 mo production seasons

early spring, the 8 mo production values are an extrapolation of the 6 mo rates. The length-frequency plots (Figs. $2 \& 3$ ) suggest that some growth occurs outside our sampling period. Perhaps the amphipods are able to utilize alternative food sources or phytoplankton remaining in the sediments from the production season. Observations made in mid-summer with a manned submersible revealed the presence of a diatom layer on the sediment surface. The decrease in production from 1986 to 1988 may be a short-term fluctuation or part of a long-term trend and further observations will be needed to make this distinction. The decline may or may not be related to predation by the growing whale population. The greatest abundance of

Table 2. Average ampeliscid amphipod production ( $g$ dry wt $\mathrm{m}^{-2}$ ) in the northern Bering Sea, 1986 to 1988

\begin{tabular}{|c|c|c|c|c|}
\hline \multirow[b]{2}{*}{ Year } & \multicolumn{2}{|c|}{6 months } & \multicolumn{2}{|c|}{8 months } \\
\hline & Production & P/B ratio & Production & $\mathrm{P} / \mathrm{B}$ ratio \\
\hline \multicolumn{5}{|c|}{ Ampelisca macrocephala } \\
\hline 1986 & 29.4 & 0.7 & 39.1 & 0.9 \\
\hline 1987 & 21.0 & 0.7 & 28.0 & 0.9 \\
\hline 1988 & 19.8 & 0.6 & 26.4 & 0.8 \\
\hline \multicolumn{5}{|c|}{ Byblis spp. } \\
\hline 1986 & 5.85 & 0.7 & 7.8 & 0.9 \\
\hline 1987 & 4.80 & 0.8 & 6.4 & 1.1 \\
\hline 1988 & 4.50 & 0.5 & 6.0 & 0.7 \\
\hline \multicolumn{5}{|c|}{ Ampelisca birulai } \\
\hline 1986 & 3.0 & 1.0 & 4.0 & 1.3 \\
\hline 1987 & 3.15 & 1.1 & 4.2 & 1.4 \\
\hline 1988 & 2.25 & 1.0 & 3.0 & 1.3 \\
\hline \multicolumn{5}{|l|}{ Totals } \\
\hline 1986 & 38.3 & 0.7 & 51.0 & 1.0 \\
\hline 1987 & 28.9 & 0.7 & 38.6 & 0.9 \\
\hline 1988 & 26.6 & 0.6 & 35.4 & 0.8 \\
\hline
\end{tabular}


whales we have observed in the study region, however, occurred during late September and early October 1986, and the major drop in amphipod density occurred between fall 1986 and spring 1987.

\section{Whale energy requirements}

Annual gray whale energy requirements can be calculated from respiration data, average whale size, and population estimates. Using the relationship between gray whale body weight and oxygen consumption of $\mathrm{V}_{\mathrm{O}_{2}}=4.1 \mathrm{~W}-5.7$ (Wahrenbrock et al. 1974), an average body weight of 19.6 metric tons (Rice \& Wolman 1971), and a conversion factor of $4.8 \mathrm{kcal} \mathrm{l}^{-1}$ of oxygen consumed (Wahrenbrock et al. 1974, Kleiber 1975), yields a mean metabolic requirement of $5.2 \times 10^{5} \mathrm{kcal} \mathrm{d}^{-1}$ whale ${ }^{-1}$. This value is quite similar to other estimates of gray whale energy requirements (Table 3 ). The mean of the various estimates, $3.8 \times 10^{5} \mathrm{kcal} \mathrm{d}^{-1}$ or $1.4 \times 10^{8}$ $\mathrm{kcal} \mathrm{yr}^{-1}$, is used in subsequent calculations. As the

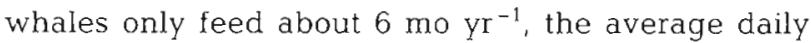
feeding rate should be double the daily metabolic rate or $7.6 \times 10^{5} \mathrm{kcal} \mathrm{d}^{-1}$.

Although other types of organisms are found in gray whale stomachs, the dominant prey are amphipods (Nerini 1984). For example, stomach contents of whales taken by Soviet whaling vessels in the Chirikov Basin consisted of $95 \%$ ampeliscids and $5 \%$ other types of amphipods (Bogoslovskaya et al. 1981). To allow for other prey items in the diet, we assume that $90 \%$ of a whale's dietary needs are obtained by feeding on ampeliscid amphipods and that capture and digestive efficiency is $80 \%$ (Thomson \& Martin 1986), which yields an annual energy requirement from amphipod predation of $1.6 \times 10^{8} \mathrm{kcal}$ per whale.

Table 3. Estimated active gray whale energy requirements

\begin{tabular}{|c|c|c|c|}
\hline Source & $\begin{array}{c}\text { Whale wt } \\
\text { (mt) }\end{array}$ & $\begin{array}{l}\text { Energy } \\
\text { requirement } \\
\left(\mathrm{kcal} \mathrm{d}^{-1}\right)\end{array}$ & $\begin{array}{l}\text { Standardized to a } \\
19.6 \mathrm{mt}^{\text {individual }} \\
\left.\text { (kcal d }^{-1}\right)\end{array}$ \\
\hline (1) & 14 & $2.7 \times 10^{5}$ & $3.7 \times 10^{5}$ \\
\hline (2) & 13.6 & $2.9 \times 10^{5}$ & $3.7 \times 10^{5}$ \\
\hline (3) & 23 & $3.0 \times 10^{5}$ & $2.6 \times 10^{5}$ \\
\hline This paper & 19.6 & $5.2 \times 10^{5}$ & $5.2 \times 10^{5}$ \\
\hline Mean & & & $3.8 \times 10^{5}$ \\
\hline \multicolumn{4}{|c|}{$\begin{array}{l}\text { - The various estimates are standardized to a popula- } \\
\text { tion mean of } 19.6 \mathrm{mt} \text { ind }{ }^{-1} \text { based on the data of Rice } \\
\text { \& Wolman (1971). The approximate weight of } 1 \mathrm{yr} \\
\text { old whales is } 6600 \mathrm{~kg}, 2 \mathrm{y} \text { olds } 9000 \mathrm{~kg} \text {, and } 3 \text { yr olds } \\
15000 \mathrm{~kg} \text {. Adult whales had an average weight of } \\
22800 \mathrm{~kg} \text {. Ca } 25 \% \text { of the population was juvenile }\end{array}$} \\
\hline \multicolumn{4}{|c|}{$\begin{array}{c}\text { Sources: (1) Rice \& Wolman (1971); (2) Sumich (1983); } \\
\text { (3) Thomson \& Martin (1986) }\end{array}$} \\
\hline
\end{tabular}

The most recent National Marine Mammal Laboratory census of the gray whale population provided an estimate of 21100 individuals in 1987 (Breiwick et al. 1988). The current estimate of annual gray whale population growth is $3.2 \%$ (Buckland in press). These figures were used to generate the population data in Table 4. During 1981 and 1982, an estimated $15 \%$ of the gray whale population fed in the Chirikov Basin (Thomson \& Martin 1986). Soviet scientists estimated the whale population for 1982 at 3300 to 3500 , or about $19 \%$ of the population, in a $3.6 \times 10^{4} \mathrm{~km}^{2}$ area of the northwest and northern Bering Sea (Berzin 1984). An intermediate value of $17 \%$ was used to estimate the number of whales feeding in the Chirikov Basin during the entire season (Table 4). Also, a large proportion of the whale population passes through the Chirikov Basin on the way into and out of the Chukchi Sea. For 1982, Thomson \& Martin (1986) estimated that 9100 $(52 \%)$ of a total population of 17600 whales passed through the Chirikov Basin and entered the Chukchi Sea, spending $6 \mathrm{~d}$ feeding in the Basin while passing in each direction. This would seem to be an underesimate. Smali numbers of yidy whales may summei at locations, such as the British Columbia coast, along the migration route (Dohl 1983, Darling 1984, Murison et al. 1984, Kim \& Oliver 1989). If about $20 \%$ of the whales remain in the Chirikov, and an allowance of $10 \%$ is made for whales distributed along the migration route, then about $70 \%$ of the whales must pass through Bering Strait. The $70 \%$ figure was used to estimate feeding requirements of transient whales (Table 4). If the more conservative value of $52 \%$

Table 4. Estimated gray whale population size 1986 to 1988 . and projected size for 2000. Estimates are subdivided into the number of whales transiting Bering Strait to feed farther north (transients) and those remaining on the feeding grounds in the Chirikov Basin (residents). Gray whale energy requirements from the Chirikov Basin for both categories of whale and total energy to be harvested were calculated using an area of $3.75 \times 10^{4} \mathrm{~km}^{2}$ A $12 \mathrm{~d}$ feeding period was used for transient whales

\begin{tabular}{|c|c|c|c|c|}
\hline & 1986 & 1987 & 1988 & 2000 \\
\hline Total population & 20425 & 21100 & 21775 & 30792 \\
\hline $\begin{array}{l}\text { No through } \\
\text { Bering Strait }\end{array}$ & 14298 & 14770 & 15243 & 21554 \\
\hline $\begin{array}{l}\text { No. residents in } \\
\text { Chirikov Basin }\end{array}$ & 3472 & 3587 & 3702 & 5235 \\
\hline $\begin{array}{l}\text { Resident energy } \\
\text { needs }\left(\mathrm{kcal} \mathrm{m}^{-2}\right)\end{array}$ & 14.8 & 15.3 & 15.8 & 22.3 \\
\hline $\begin{array}{l}\text { Transient energy } \\
\left.\text { needs (kcal } \mathrm{m}^{-2}\right)\end{array}$ & 3.5 & 3.6 & 3.7 & 5.2 \\
\hline $\begin{array}{l}\text { Total energy } \\
\left.\text { needed (kcal m}{ }^{-2}\right)\end{array}$ & $\overline{18.3}$ & $\overline{18.9}$ & $\overline{19.5}$ & $\overline{27.5}$ \\
\hline
\end{tabular}


(Thomson \& Martin 1986) were used, the calculated transient whale energy requirements would only decrease about $1 \mathrm{kcal} \mathrm{m}^{-2}$. The feeding area of the gray whales in the northern Bering Sea used in the calculations was $3.75 \times 10^{4} \mathrm{~km}^{2}$ (Nerini 1984). The estimated total whale energy requirement in the Chirikov Basin increased from $18.3 \mathrm{kcal} \mathrm{m}^{-2}$ in 1986 to $19.5 \mathrm{kcal} \mathrm{m}^{-2}$ in 1988 (Table 4). The projected energy requirement in the year 2000, if the gray whale population continues to grow at the current rate of $3.2 \%$, would be approaching $30 \mathrm{kcal} \mathrm{m}^{-2}$.

For 1986, the estimated whale energy requirement represents 8 to $11 \%$ of the estimated amphipod production (Table 2) and for 1988,13 to $18 \%$ of production. Using average production for 1986 to 1988, projected energy requirements in 2000 would be 15 to $21 \%$ of production. If production remained at the 1988 levels, 18 to $25 \%$ of production would be needed to support the whale population by 2000 .

There are a number of potential errors in calculating how many whales can be supported by amphipod production and the amount of energy harvested by the whales, including estimates of the number of whales feeding in the Chirikov Basin and the estimated area of the amphipod bed. With regard to using $3.75 \times 10^{4} \mathrm{~km}^{2}$ for the whale feeding and amphipod production area, the only other published estimates are $3.63 \times 10^{4} \mathrm{~km}^{2}$ (Berzin 1984), $2.35 \times 10^{4} \mathrm{~km}^{2}$ (Thomas \& Martin 1986), and, based on a side-scan sonar study of the distribution of whale feeding pits, $2.2 \times 10^{4} \mathrm{~km}^{2}$ (Johnson \& Nelson 1984, Nelson et al. 1987). The side-scan based estimate is probably too low. Utilizing a submersible, we have observed bottom currents and surge sufficient to move sand grains, and excavations made with a suction device began filling in within minutes (unpubl. own obs.J. Using lower areal estimates increases the amount of energy that must be harvested per unit area and decreases the total number of whales supportable by the amphipods. For example, if the estimate of $2.35 \times 10^{4} \mathrm{~km}^{2}$ is used in the above calculations, the resident and transient whales would harvest about $12 \mathrm{kcal} \mathrm{m}^{-2} \mathrm{yr}^{-1}$ more than shown in Table 4 .

Alternatively, to calculate the number of resident whales supportable by amphipod production (Table 5), a $10 \%$ energy transfer between trophic levels was used (Crisp 1975, Mann 1982, Parsons et al. 1984) and, of the transfer, $19 \%$ (Table 4) was allocated to transient whales. Only the maximum estimated feeding area and a 1986-level production season of 8 mo would support the calculated number of resident whales (Table 4) feeding in the Chirikov Basin.

The above calculations make no allowance for other sources of predation on the amphipods. Work in progress in the study region has shown that the amphipods are also preyed upon by several species of
Table 5. Calculated number of gray whales supportable by amphipod production in 1986 and in 1988 using minimum and maximum areal estimates of the whale feeding area and 6 mo and 8 mo production seasons

\begin{tabular}{|c|c|c|c|c|}
\hline \multirow[t]{3}{*}{ Year } & \multicolumn{4}{|c|}{ Area } \\
\hline & \multicolumn{2}{|c|}{$2.35 \times 10^{4} \mathrm{~km}^{2}$} & \multicolumn{2}{|c|}{$3.75 \times 10^{4} \mathrm{~km}^{2}$} \\
\hline & $6 \mathrm{mo}$ & $8 \mathrm{mo}$ & $6 \mathrm{mo}$ & $8 \mathrm{mo}$ \\
\hline 1986 & $1916^{\circ}$ & 2546 & 3056 & 4063 \\
\hline 1988 & 1332 & 1772 & 2126 & 2829 \\
\hline \multicolumn{5}{|c|}{$\begin{array}{l}\text { Sample calculation: } 10 \% \text { of production for } 6 \text { mo in } 1986 \\
\text { was } 16.1 \mathrm{kcal} \mathrm{m}^{-2} \text { (Fig. } 7 \text { ) or } 3.78 \times 10^{11} \mathrm{kcal} \mathrm{Yr}^{-1} \text { for } \\
2.35 \times 10^{4} \mathrm{~km}^{2} \text { Dividing annual production for this area } \\
\text { by average annual energy requirement of } 1.6 \times 10^{8} \mathrm{kcal} \\
\text { per whale yields } 2365 \text { whales. Of this total, } 19 \% \text { would } \\
\text { be transient whales (Table } 4 \text {; transient whale energy re- } \\
\text { quirements are } 19 \% \text { of the total energy requirement), } \\
\text { yielding } 1916 \text { resident whales }\end{array}$} \\
\hline
\end{tabular}

fish, lysianassid amphipods, crangonid shrimp and the crabs Chionoecetes opilio and Hyas lyrata (unpubl. own. obs.). Energy demands by these other predators have not yet been estimated but appear to be substantial. Benthic ampeliscid amphipods represent the first consumer level in the northern Bering Sea ecosystem, similar to copepods in oceanic food webs.

\section{DISCUSSION}

Ampeliscid populations in temperate environments often produce multiple cohorts in a single season (Mills 1967, Klein et al. 1975, Hastings 1981, Carrasco \& Arcos 1984, Collie 1985, Dauvin 1988). In contrast, populations of the larger, dominant ampeliscid species Ampelisca macrocephala and Byblis spp., in the Chirikov Basin are composed of 4 to 5 or more cohorts, one from each of several preceding years. In addition, ampeliscid molting rates in the Chirikov Basin are slow with respect to rates measured at warmer locations. Adult and subadult specimens in the Chirikov basin may not molt at all during summer; instead they feed and accumulate energy reserves for subsequent molting and reproduction during winter or early spring (Highsmith \& Coyle 1991). We previously postulated that molting and growth rates are decoupled, with molting rates being regulated by temperature. At colder temperatures, the amphipods molt less frequently and, thus, accumulate more biomass between molts. This slow maturation process results in much larger, older adults than would be the case in a warmer location. Arctic amphipods have low fecundity and possibly low mortality rates compared to many other invertebrate taxa (Highsmith \& Coyle 1991). Amphipod rates of increase in length are approximately 
linear and biomass accumulation rates are exponential. Most secondary production by organisms with the above life history features and population structure should occur in the older, rather than younger, age classes (Morin et al. 1987), as is the case for the ampeliscid amphipods included in this study (Highsmith \& Coyle 1991). Consequently, the high mortality among older age classes of Ampelisca macrocephala between October 1986 and June 1987 had a major impact on subsequent amphipod production in 1987 . 1988, and probably beyond.

The secondary production rates of the Chirikov Basin ampeliscid community are higher than those of any other major benthic community studied to date (Highsmith \& Coyle 1990). Much of the production, however, results from the development of dense populations and high biomass. The production to biomass ratios of the Chirikov Basin ampeliscids are about 0.7 to 1.3 while $\mathrm{P} / \mathrm{B}$ ratios for temperate ampeliscid species range from 1.4 to 5.0 (Collie 1985, Dauvin 1988, Highsmith \& Coyle 1991). Low P/B ratios in amphipod communities are a reflection of long generation times and tend to uccus wilłı low water iemperdiures (Dauvin 1989). Because amphipods do not have asymptotic growth curves, $\mathrm{P}: \mathrm{B}$ ratios are not correlated with productivity and their only comparative value appears to be as an index of number of generations per year (Highsmith \& Coyle 1991).

Any perturbation causing extensive mortality within a high-latitude ampeliscid population having low fecundity and long generation times would result in a marked decrease in secondary production rate. The approximate $28 \%$ decline in Ampelisca macrocephala production between 1986 and 1987 resulted from population decreases in the older age classes. Disturbed amphipod populations, with low fecundity and direct development, tend to recover more slowly than invertebrates with pelagic larvae and high fecundity (Dauvin 1989). Populations of A. sarsi reduced by 99.3\% following the 'Amoco Cadiz' oil spill, for example, had recovered to only $39 \%$ of their original maximum densities 10 yr after the spill (Dauvin 1989). Chirikov Basin ampeliscid populations, with their longer generation times and lower growth rates relative to maturation time, would probably take considerably longer to recover from major population disruptions. The lower production in 1988 is probably a reflection of the long recovery period required by the slow growing Arctic ampeliscids. These factors indicate that Arctic ampeliscid communities may be quite sensitive to predation by the expanding gray whale population.

Both ampeliscid amphipod production data and estimates of gray whale energy requirements suggest that the gray whale population may be approaching the carrying capacity of the amphipods, notwithstanding the impact of other predators on the amphipods. Further, Soviet catch records show a substantial decrease in pregnant females during the 1980 s from $44 \%$ to just $2.6 \%$ in 1989 (Blokhin, cited in Braham \& Donovan in press), and the number of live calves in Mexican waters in 1990 was low (Braham \& Donovan in press). These observations could have a number of explanations, but inadequate nutrition for adult females would result in reduced reproduction. It will be interesting to see if the gray whale population continues to increase or if these observations indicating reduced reproduction signal the beginning of a leveling off.

Of course there are several potential sources of error in our calculations. Estimating the size of the gray whale feeding population in the Chirikov Basin is difficult and it is possible that the whales shift their feeding activities to different areas when amphipod densities are reduced or that they exhibit sufficient territorial behavior to limit the number of whales utilizing the amphipod bed. Possibly the whales feed more in the southern part of their range than thought î̃orris ei ai. 1983), but the feeding period in the north would still be about 3 times longer than the time spent along the Mexican coast and must still represent the major feeding period (Pike 1962, Rice \& Wolman 1971, Oliver et al. 1983, Braham 1984, Nerini 1984). Whaling records indicate that both southbound and northbound migrating whales have empty stomachs in the southern portion of the migration route (Scammon 1874, Andrews 1914, Pike 1962). In contrast, $85 \%$ of whales landed by Soviet whalers in the Bering and Chukchi Seas had food in their stomachs (Zimushko \& Lenskaya 1970). Weight loss between the southward and northward migrations ranged from 11 to $29 \%$ and southward migrating whales yielded 2.5 to 3 times the oil, meal and meat of northbound individuals (Rice \& Wolman 1971). Further, studies within the coastal lagoons of Baja California indicate that the whales do not feed even though feeding-type behaviors may be exhibited (Oliver et al. 1983). Thus, the long migration to northern waters is undertaken in order to feed in a location where food is sufficiently abundant that nearly an entire year's energy requirement can be harvested in about 6 mo.

\section{CONCLUSIONS}

The Chirikov Basin ecosystem entertains a high phytoplankton primary production, with estimated annual rates of about $300 \mathrm{~g} \mathrm{C} \mathrm{m}^{-2}$ (Sambrotto et al. 1984, Walsh et al. 1989) or about $3200 \mathrm{kcal} \mathrm{m}^{-2}$ (Crisp 1975), rapid transfer of a significant proportion of the 
phytoplankton to the bottom (Highsmith \& Coyle 1990), high benthic amphipod production and intensive harvesting of the amphipods by a steadily expanding gray whale population. The calculated annual energetic requirement of the Chirikov gray whale population is near or above the commonly accepted $10 \%$ ecological transfer efficiency between trophic levels (Crisp 1975, Mann 1982, Parsons et al. 1984). If whale predation reaches the point where amphipod populations decline, the amphipods would be slow to recover because of their low fecundity and long generation times (Highsmith \& Coyle 1991). Such a longterm alteration in food webs and energy flow through the ecosystem could alter the ecosystem structure, leading to colonization by other benthic species, further impeding amphipod recovery.

Acknowledgements. We greatly appreciate the contributions to this work of Carol Winiecke, Tama Rucker, J. McDonald and A. Paul; several students including F. Adams, A. Blanchard, J. Carpenter, S. Clay, M. Derenoff, D. Ferris S. Fox, S. Hartz, T. Henry, H. Kim, G. Koontz, B. Leal, G. Owens, P. Ribbens, F. Rivers, L. Shelley, C. Saccheus, C. Sullivan, R. Sundown, S. Viereck, J. Warburton, and $\mathrm{K}$. Weller; the entire crew of the RV 'Alpha Helix'; marine technicians D. Boisseau, S. Ellis, D. Leech and M. Testarmata; Dr R. Elsner for helpful discussion; and anonymous reviewers for constructive comments. This research was supported by National Science Foundation, Division of Polar Programs, grant DPP-8509843. The submersible work was supported by NOAA's National Undersea Research Program through the West Coast National Undersea Research Center at the University of Alaska Fairbanks.

\section{LITERATURE CITED}

Andrews, R. (1914). Monographs of the Pacific Cetacea. I. The California gray whale (Rhachianectes glaucus Cope) Mem. Am. Mus. nat. Hist. (New Ser.) 1: 227-287

Berzin, A. A. (1984). Soviet studies of the distribution and numbers of the gray whale in the Bering and Chukchi Seas, from 1968 to 1982. In: Jones, M. L., Swartz, S. L., Leatherwood, S. (eds.) The gray whale Eschrichtius robustus. Academic Press, New York, p. 409-450

Blokhin, S. A., Vladimirov, V. L. (1981). Pitanie serykh kitov Kaliforniisko-Chukotschkoi populyatsii v vodakh Chukotskogo poluostrova $v 1980 \mathrm{~g}$. (Feeding of the gray whales of the California-Chukchi population in the Chukchi Peninsula waters in 1980.) In: Nauchnoissledovatelskie raboty po moskim mlekopitayushchim severnoi chasti Tikhogo okeana v 1980/1981 gg. Proekt 02.05-61 Morskie mlekopitayushchie, Soglasheniya SSSR-SShA o sotrudnichestve v oblasti okhrany okruzhayushchei sredi. Moscow 1981, p. 88-98

Bogoslovskaya, L. S., Votrogov, L. M., Semenova, T. M. (1981). Feeding habits of the gray whales off the Chukotka Peninsula. Rep. Int. Whal. Comm. 31: 507-510

Braham, H. W. (1984). Distribution and migration of gray whales in Alaska. In: Jones, M. L., Swartz, S. L., Leatherwood, S. (eds.) The gray whale Eschrichtius robustus. Academic Press, New York, p. 249-266
Braham, H. W., Donovan, G. P. (eds.) (in press). Comprehensive assessment of whale stocks: gray whale Eschrichtius robustus. Int. Whaling Comm., Cambridge, UK, Special Issue 14

Breiwick, J. M., Rugh, D. J., Withrow, D. E., Dahlheim, M. E., Buckland, S. T (1988). Prelıminary population estimate of gray whales during the $1987 / 88$ southward migration. International Whaling Commission Scientific Committee, San Diego, Doc. SC/40/PS12

Brownell, Jr., R. (1977). Current status of the gray whale. Rep. Int. Whal. Commn 27.209-211

Buckland, S. T (in press.) Estimated trends in abundance of California gray whales from shore counts, 1967/68 to 1987/88. In: Braham, H. W., Donovan, G. P. (eds.) Comprehensive assessment of whale stocks: gray whale Eschrichtius robustus. Int. Whaling Comm., Cambridge, UK, Special Issue 14

Carrasco, F. D. Arcos, D. F. (1984). Life history and production of a cold-temperate population of the sublittoral amphipod Ampelisca araucana. Mar. Ecol. Prog. Ser. 14: $245-252$

Coachman, L. K., Aagaard, K., Tripp, R. B. (1975). Bering Strait. The regional physical oceanography. Univ. Washington Press, Seattle

Collie, J. S. (1985). Life history and production of three amphipod species on Georges Bank. Mar. Ecol. Prog. Ser. 22:229-238

Coyle, K. O., Highsmith, R. C. (1989). Arctic ampeliscid amphipods: three new species. J. Crustacean Biol. 9: 157-175

Crisp, D. J. (1975). Secondary productivity in the sea. In: Productivity of world ecosystems. Proc. International Biological Program (IBP) Symp., Seattle, 1972. National Academy of Sciences, Washington, D.C., p. 71-89

Darling, J D. (1984). Gray whales off Vancouver Island, British Columbia. In: Jones, M. L., Swartz, S. L., Leatherwood, S. (eds.) The gray whale Eschrichtius robustus. Academic Press, New York, p. 267-287

Dauvin, J.-C. (1988). Biologie, dynamique, et production de populations de crustaces amphipodes de la Manche occidentale. 1. Ampelisca tenuicomis Liljeborg. J. exp. mar. Biol. Ecol. 118: 55-84

Dauvin, J.-C. (1989). Life cycle, dynamics and productivity of Crustacea-Amphipoda from the western English Channel. 5. Ampelisca sarsi Chevreux. J. exp. mar. Biol. Ecol. 128: $31-56$

Dickinson, J. J. (1982). The systematics and distributional ecology of the family Ampeliscidae (Amphipoda: Gammaridea) in the northeastern Pacific region. I. The genus Ampelisca. Natl. Mus. Nat. Sci. (Ottawa) Publs Biol. Oceanogr. 10: 1-39

Dickinson, J. J. (1983). The systematics and distributional ecology of the Superfamily Ampeliscoidea (Amphipoda: Gammaridea) in the northeastern Pacific region. II. The genera Byblis and Haploops. Natl. Mus. Nat. Sci. (Ottawa) Publs Nat. Sci. 1. 1-38

Dohl, I P. (1983). Cetaceans of central and northern California 1980-83: status, abundance and distribution. U.S. Miner. Manage. Serv. Outer Continental Shelf Study. Minerals Management Service 94-0045

Grebmeier, J. M. McRoy, C. P., Feder, H. M. (1988). Pelagicbenthic coupling on the shelf of the northern Bering and Chukchi Seas. l. Food supply source and benthic biomass. Mar. Ecol. Prog. Ser. 48: 57-67

Grebmeier, J. M., Feder, H. M., McRoy, C. P. (1989). Pelagicbenthic coupling on the shelf of the northern Bering and Chukchi Seas. II. Benthic community structure. Mar. Ecol. Prog. Ser. 51: 253-268 
Gurjanova, E. F. (1951). Amphipoda Gammaridae of the seas of the USSR and adjoining waters. Keys to the fauna of the USSR. Zool. Inst. Acad. Sci. USSR, No 41:1-1031

Hastings, M. H. (1981). The life cycle and productivity of an intertidal population of the amphipod Ampelisca brevicornis. Estuar. coast. Shelf Sci. 12: 665-677

Hazard, K. F., Lowry, L. F. (1984). Benthic prey in a bowhead whale from the northern Bering Sea. Arctic 37: 166-168

Henderson, D. A. (1984). Nineteenth century gray whaling: grounds, catches and kills, practices and depletion of the whale population. In: Jones, M. L., Swartz, S. L., Leatherwood, S. (eds.) The gray whale Eschrichtius robustus. Academic Press, New York, p. 159-186

Highsmith, R. C., Coyle, K. O. (1990). High productivity of northern Bering Sea benthic amphipods. Nature, Lond. 344: $862-864$

Highsmith, R. C., Coyle, K. O. (1991). Amphipod life histories: community structure, impact of temperature on decoupled growth and maturation rates, productivity, and P:B ratios. Am. Zool. 31. 861-873

Johnson, K. R., Nelson, C. H. (1984). Side-scan sonar assessment of gray whale feeding in the Bering Sea. Science 225: $1150-1152$

Jones, M. L., Swartz, S. L., Leatherwood, S. (1984). The gray whale Eschrichtius robustus. Academic Press, New York, p. xxi-xxiv

Kim, S. L., Oliver, J. S. (1989). Swarming benthic crustaceans in the Bering and Chukchi seas and their relation to geographic patterns in gray whale feeding Can. J. Zool. 67: $1531-1542$

Kleiber, M. (1975). The fire of life: an introduction to animal energetics. Robert E. Krieger Publ. Co., Huntington, NY

Klein, G., Rachor, E., Gerlach, S. A. (1975). Dynamics and productivity of two populations of the benthic tube-dwelling amphipod Ampelisca brevicornis [Costa) in Helgoland Bight. Ophelia 14: $139-159$

Lowry, L. F., Frost, K. J. (1984). Foods and feeding of bowhead whales in western and northern Alaska. Sci. Rep. Whales Res. Inst. 35: 1-16

Mann, K. H. (1982). Ecology of coastal waters: a system's approach. Univ. California Press, Berkeley

Mills, E. L. (1967). The biology of an ampeliscid amphipod crustacean sibling species pair. J. Fish. Res. Bd Can. 24: 305-355

Morin, A., Mousseau, T A., Roff, D. A. (1987). Accuracy and precision of seconday production estimates. Limnol. Oceanogr. 32: 1342-1352

Murison, L., Murie, D., Morin, K., da Silva Curiel, J. (1984). Foraging of the gray whale along the west coast of Vancouver Island. British Columbia. In: Jones, M. L., Swartz, S. L., Leather wood, S. (eds.) The gray whale Eschrichtius robustus. Academic Press, New York, p. 451-463

Nelson, C. H., Johnson, K. R., Barber, J. H., Jr (1987). Gray whale and walrus feeding excavation on the Bering Shelf, Alaska. J. sedim. Petrol. 57: 419-430

Nerini, M. (1984). A review of gray whale feeding ecology. In: Jones, M. L., Swartz, S. L., Leatherwood, S. (eds.) The gray whale Eschrichtius robustus. Academic Press, New York, p. $423-450$

This article was submitted to the editor
Nerini, M. K., Oliver, J S. (1983). Gray whales and the structure of the Bering Sea benthos. Oecologia 59: $224-225$

Norris, K., Villa-Ramirez, B., Nichols, G., Wursig, B., Miller, K (1983). Lagoon entrance and other aggregations of gray whales, Eschrichtius robustus. In: Payne, R. (ed.) Communication and behavior of whales. Westview Press, Boulder, p. 259-293

Oliver, J. S., Slattery, P. N., Silberstein, M. A., O'Conner, E. F. (1983). A comparison of gray whale, Eschrichtius robustus, feeding in the Bering Sea and Baja California. Fish. Bull. U.S. 81:513-522

Parsons, T. R., Takahashi, M., Hargrave, B. (1984). Biological oceanographic processes. Pergamon Press, Oxford

Pike, G. C. (1962). Migration and feeding of the gray whale (Eschrichtius robustus). J. Fish. Res. Bd Can. 19: 815-838

Ray, C. G., Schevill, W. E. (1974). Feeding of a captive gray whale, Eschrichtius robustus. Mar. Fish. Rev. 36: 31-38

Reilly, S. B., Rice, D. W., Wolman, A. A. (1983). Population assessment of the gray whale, Eschrichtius robustus, from California shore censuses, 1967-80. Fish. Bull. U.S. 81: $267-281$

Rice, D. W., Wolman, A. A. (1971). The life history and ecology of the gray whale (Eschrichtius robustus). Am. Soc. Mammologists, Spec. Publ. 3: 1-142

Sambrotto, R. N., Goering, J. J., McRoy, C. P. (1984). Large yearly production of phytoplankton in the western Bering Strait. Science 225: $1147-1150$

Scammon, C. M. (1874). The marine mammals of the northwestern coast of North America. John H. Carmany and Co., San Francisco

Stoker, S. W. (1981). Benthic invertebrate macrofauna of the eastern Bering/Chukchi continental shelf. In: Hood, D. W., Calder, J. A. (eds.) The eastern Bering Sea shelf: oceanography and resources. Office of Marine Pollution Assessment, NOAA, Univ. Washington Press, Seattle. p. $1069-1090$

Sumich, J. L. (1983). Swimming velocities, breathing patterns, and estimated costs of locomotion in migrating gray whales, Eschrichtius robustus. Can. J. Zool. 61: 647-652

Swartz, S. L., Jones, M. L. (1987). Gray whales make a comeback. Nat. Geogr. 171: 754-771

Thomson, D. H., Martin, L. R. (1986). Feeding ecology of gray whales (Eschrichtius robustus) in the Chirikof Basin, summer 1982. U.S. Dep. Comm., NOAA, OCSEAP Final Rep. 43(1986): 377-460

Wahrenbrock, E. A., Maruschak, G. F., Elsner, R., Kenney, D. W. (1974). Respiration and metabolism in two baleen whale calves. Mar. Fish. Rev. 36(4): 3-9

Walsh, J. and 19 others. (1989). Carbon and nitrogen cycling within the Bering/Chukchi Seas: source regions for organic matter effecting AOU demands of the Arctic Ocean. Prog. Oceanogr 22: 277-359

Wildish, D. J., Peer, D. (1981). Methods for estimatıng secondary production in marine Amphipoda. Can. J. Fish Aquat. Sci. 38: 1019-1025

Zimushko, V. V., Lenskaya, S. A. (1970). On the feeding of gray whales in their feeding areas. Ekologiya (Sverdlovsk) 3: $26-35$

Manuscnpt first received: October 8, 1991

Revised version accepted: April 14, 1992 